\title{
Universal Crime Theories and Women
}

\author{
Dr. Uma Tripathi*
}

Lecturer (BA LLB Five Year Integrated Course) Central University of Allahabad, India

DOI: $10.36348 /$ sijlcj.2019.v02i11.003

| Received: 20.08.2019 | Accepted: 27.08.2019 | Published: 14.11.2019

*Corresponding author: Dr. Uma Tripathi

\section{Abstract}

The present study attempts to locate women in the universal crime theories which seem to be developed from male subjects and validated on them too. Due to the increasing equality in status and opportunity between men and women the line between male and female crime is getting thinner. There are many universally accepted theories which apparently apply to male criminals but on lifting the veil on them and studying minutely we discover that they equally apply to female criminals too. No doubt any theory is weak if it does not apply to half of the population which experiences the same deprivations in the same environment, family structures and economic conditions. The research revolves around the twin factors, first that the theories of crime should be able to take account of both men's and women's behavior and to highlight those factors which operate differently on men and women and second that if a particular theory helps us to understand female crime better this would be a great achievement for criminology. The relevant matter for consideration is whether these 'manmade' and 'made for men' do explain female crime and if few of them or all of them do so then to what extent?

Keywords: Universal Crime Theories and Women.

Copyright @ 2019: This is an open-access article distributed under the terms of the Creative Commons Attribution license which permits unrestricted use, distribution, and reproduction in any medium for non-commercial use (NonCommercial, or CC-BY-NC) provided the original author and source are credited.

\section{INTRODUCTION}

It is true that theories of criminality have been developed from male subject and validated on male subjects and. Also these theories are generalized to all criminals, defendants and prisoners. Allison Morris says that generalizations from research on women on the other hand do not occur [1]. It is assumed that the theories will apply to women; but many do not. Allison further says- "It means that first these theories are special theories about men's crime and secondly that doubt must arise about a particular theory's validity as a general theory if it does not apply to women. A theory is weak if it does not apply to half of the potential criminal population; woman after all experience the same deprivations, family structures and so on that men do. To study only men or boys to assess whether or not delinquency springs from, for ex poverty makes little sense. Similarly to refer to 'subculture style' of working-class boys as a solution to the problems of redevelopment, housing, depopulation and community solidarity begs an important question: how do working class girls solve these problems? Theories of crime should be able to take account of both men's and women's behavior and to highlight those factors which operate differently on men and women. Whether or not a particular theory helps us to understand women's crime better is of fundamental not marginal, significance for criminology [2]. The matter for consideration at present is whether the theories of crime which are 'man made' do explain women's crime and if few of them or all of them do then to what extent?

As regards modern theories related to female criminality, today women have a wide variety of chores which were not available to them before. It would be foolish to assume that female criminality may be explained by any one theory in the same way as in the case of criminality of men, but the fact remains true that sociological factors and environmental influences appear to have greater credibility in explaining criminal behavior of male and female alike. The dynamics of social and economic condition, environment and cultural, biological and physiological factors must not be left out when studying crime in relation to human being is it male or female. The theory of feminism

Applies to the invention of the liberated woman. Freda Adler believed that the dramatic upsurge in female criminal activity was caused by the arrival of the second wave of feminism during the 1970s when women demanded equal opportunity in all the fields at par with men. Once out in the rough world many determined women forced their way into the world of 
major crimes such as murder, robbery and white collar crime [3]. Female white collar crime has increased since the liberation of women but crime statistics still show that women are still primarily shoplifters. Freda believed that emancipation is the cause of the surge in the incidence of criminality of women but it appears from the studies that women are forced into criminality due to pitiful conditions like unemployment, lack of educational opportunities, domestic violence and divorce or separation. This also explains the increase in petty theft, robbery and homicide. There are many universal accepted theories of crime which though apparently apply to male criminals, but the fact remains true that they equally apply to female criminals too. Here we discuss few 'man made' crime theories and see whether they apply to female crime too and to what extent.

\section{Demonological Theory}

This theory is the most primitive one. A criminal was regarded to be under the control of some demon spirit instigating him to commit misdeeds. The affected person was subject to deterrent punishment and even killed to destroy the supposed evil spirits possessing his body and controlling his actions. In 1692 two harmless women were thought to be possessed by devil and had to be eliminated [4]. The belief in witches, evil spirits and the efficacy of charms is deeply rooted in all the societies of the world and this is true that it is mainly the fairer sex which is always presumed to be possessed by evil spiits[5]. The belief in demonism and witch practice still persists in many cultures especially Asian ones

And in the Indian rural sides we now and then hear of hapless lower status women being tortured and sometimes being killed by frenzied mob of ignorant people to get rid of the demon possessing the human body. The belief that evil spirits easily overpower women has been handed down the centuries and even today in this civilized world in many countries and societies innocent females have been punished and killed due to the superstitious beliefs of people. According to Shubhra Ghosh, Rao in 1962 found that in Indian rural side women may be guided by superstition to commit crimes[6]. Ben Yehuda held that witch persecutions were not only dysfunctional but an outrageous failure demonstrating only useless sacrifice of life and moral degradation. According to him witch craze was a unique historical combination of accusation against people especially women of whom the over whelming majority were probably completely innocent. The supposed witches were considered worse than the worst criminals. There was this massive movement for over three centuries in Europe and no doubt it was nothing else than just some big mistake and a failure. Women victimized were declared as criminals instead[7]. "The pathological fear of female deviance and criminality is reminiscent of the 'witch hunts' of history which as Heidensohn suggests is a powerful and recurring popular image of deviant women as especially evil, depraved and monstrous... used by scientific criminologists which not only had a stigmatizing effect but also had unfortunate consequences for the treatment of women offenders [8]." Suspicion of women had deep roots in history. In their hand book for witch hunters, Kramer and Sprenger referred to women as beautiful to look upon, but contaminating to touch; once awakened, their carnal lust was viewed as insatiable. Thus it was primarily woman, not man, whom it was believed, the devil used as an instrument for his evil designs [9].

\section{Free Will Theory}

Beccaria, Bentham and Romilly are the pioneers of Classical School of which the Free Will Theory is an important part. According to this school all men are self-seeking and hence they commit crimes. This school rejects the theory of offenders being possessed by some evil spirit. Man is possessed of free will and acts on the basis of the pleasure and pain (hedonism), the simplicity of this theory lies in the fact of emphasis on individual rather than the social surrounding of the criminal. To quote Prof. N.V. Paranjape, "It goes to the credit of Beccaria who denounced the earlier concepts of crime and criminals which were based on religious fallacies and myths and shifted emphasis on the need for concentrating on the personality of an offender in order to determine his guilt and punishment[10]. The theory does not mention what is the effect of 'free will' on women. Female criminality it seems at that time was a trivial and unimportant matter and crime was considered the bastion of men only. This notion was appropriate at that time because women had no free will in the patriarchal society and men controlled their will, whims and fancies.

\section{The Organic Deficiency Theory}

This theory was the outcome of the endeavors of the Italian School of Criminology. Cesare Lombroso is termed as father of modern criminology and is famous for his biological positivism. In his book 'Criminal Man' Lombroso used Darwinian principles of evolution to back up his ideas on inferiority of criminals to honest people, of blacks to whites and also women to men. He seemed to be impressed by social Darwinism that referred to the idea that individual or groups develop certain physical and psychological characteristics to allow them to function most efficiently. He did not understand the equality in gender roles [11] and in relation to female criminality he was a sexist believing in sexual hierarchy that was supported with the measurements of female skull which in consequence supported his theory of atavism. He

Deduced that female criminals were rare with few signs of degeneration as they had evolved less than men due to the inactive nature of their lives and further due to inherent passiveness hesitated from breaking the law, He also opined that they lacked the intelligence and initiative to become criminals [12]. For Lombroso 
women who were born criminals were monsters belonging more to the male than the female sex with the combination of worst aspect of womanhood such as cunningness and deceitfulness with the criminal inclinations and callousness of men [13]. Lombroso argued that prostitutes evolved in a way that made them unusually attractive while violent women evolved an unusual strength and vigour [14]. Lombroso along with Ferrero studied the craniums of female offenders and the moles and tattoos of imprisoned women and came to the conclusion that there was a presence of degeneration such as misshapen skull or thick black hair though he also admitted that they did not fit exactly into his theory of atavism. In fact he himself admitted that there were only a few numbers that represented the 'true' criminal type' of born criminal [15]. The concept of atavism could not be accurately proven in his study and he had no choice but to use the theory of biological determinism to enrich his studies. Enrico Ferri believed in the thesis of his tutor Lombroso along with giving emphasis on environmental factors too. On female criminality he ratified the view of Lombroso and went a step ahead by emphasizing on the role of environment factors over the female criminal [16].

\section{Endocrinological Theory of Crime}

This theory propounds that the resultant criminal behavior is attributed to malfunctioning of one or more ductless glands [17]. In a more specifically biological approach it has been suggested (Money and Erhardt and Rose et al. that the genetic passivity of females is related to different brains of men and women and difference

In hormones between men and women [18]. Soon after birth a rat's brain becomes either male or female. If there is a predominance of female hormones (estrogens) the brain becomes female; if a predominance of male hormones (androgens) the brain becomes male. If early in life a female is injected with androgens she becomes aggressive and indistinguishable from a male and an early castrated male will be more passive later in life. It has been claimed that these tests and some rather more complex ones involving monkeys show that some may well be true for humans [19]. It is believed by many that a female who has level of testosterone a little higher than the rest of her kind would be more active, masculine, aggressive and hence be lead easily into criminality whereas a male who has less testosterone compared to others males would be passive and a little bit feminine [20].

\section{Heredity Theory}

Richard Dugdale in 1877 studied the family tree of the Jukes in New York and came to the conclusion that criminality would always run in the family [21]. The studies of Sheldon and Eleonor Glueck claimed to show that a father's criminal conduct was the best predictor of his son's future criminal behavior
[22]. Goring also argued that criminal tendencies are basically inherited and not only the physical features but the contents of the genetic material passed on from the parents. If the parents were criminals the children would in high probability be criminals too later in their lives [23]. The factor of heredity does not differentiate between a male or a female and both are subject to same consequences due to the same genes of their parents. Some tribes in India are nomadic and habitually indulge in criminal activities. It is presumed by many people that heredity is to be blamed for this but the truth is that this may be due to the behavior which they learn from their

Early childhood and with passage of time they become accustomed to it. Likewise the daughter of a prostitute does not become the same due to the genes inherited from her mother but due to the surrounding environment to which she is subjected right from her birth. "Researches however have certainly come far in their progression to the point where there is a large consensus of the fact that genes do influence behavior to a certain extent. Although not as widely publicized it is the belief of the author that these same researches reiterate that environmental factors account for what cannot be explained by genes. Therefore it seems obvious to reach to the conclusion that an individual's antisocial or criminal behavior can be the result of both his genetic background and the environment in which he was raised[24]." Same rule applies to women too because neither genes nor environment is specifically gender specific.

\section{Ecological Theory}

This theory relates delinquency with specific geographical areas. Clifford R. Shaw in his 'Delinquency Area' noted the delinquency rates high in the centre of Chicago. The delinquency rate decreased as one moved from the centre to the peripheral areas [25]. The delinquent areas are the product of lack of social control. The further study of other countries by Shaw confirmed the same conditions as in Chicago. In the ecology the areas which provide opportunity for criminal endeavors would be indeed the most crimeladen. Shaw emphasizes that the poor housing, low education, impoverishment of families are not really significant factors for criminalistic behavior, they are merely symptomatic of degenerative process]26]. Frederic Thrasher in his work 'The Gang' made study of gangs in Chicago which were effective near the factories and rail roads. According to him crime originates on the edges of civilization and respectively in the communities failing to adjust to the normal conditions [27].

Human ecological theory facilitates an investigation into the ways in which social structure produces this convergence which allows illegal activities to feed upon the legal activities of everyday life. Dispersion of activities away from households and 
families increases the opportunities for crime and generates higher crime rates[28]. This holds true for the rising female gangs which have become an interesting phenomenon globally. In the past females used to hold weapons or drugs for the male members but gradually while their male counterparts landed in jails they began to run the gangs themselves. A vast majority of women in gangs have brothers or boyfriends in gangs. The place which they find most suitable to dwell and pursue their criminal designs is the most suitable unit of ecology. In India the dacoit queens have infested the ravines of Madhya Pradesh and Rajasthan these being a safe haven and a hard nut to crack for the law enforcement authorities who do not know the total geography of these mysterious landscapes. To quote Prof. N.V. Paranjape -“. In India, the impact of ecology on crime is apparently to be seen in dacoit-infested forest regions and ravines of Rajasthan, Madhya Pradesh and Uttar Pradesh where opportunities for escape and detection are plenty[29]."

\section{Psycho-Analytical Theory}

Sigmund Freud is the propounder of the Psycho-Analytical theory which comprises of 'id', 'ego' and 'super ego'. 'Id' is the basic biological and physical urge e.g. hunger, sex, and affection etc. It always operates in unconscious manner. 'Ego' is the conscious personality which is always aware of the rightful methods of acquiring the worldly things and to do otherwise would cast aspersions on it. The relationship between 'id' and 'ego' brings out 'superego' which ultimately controls the actions of the human being. There is a constant conflict in progression between 'id', 'ego' and 'superego' and the resultant behavior of a man is the consequence of this conflict. Due to weakness of 'ego' personality.

Problems arise resulting in disapproved behavior. Also where the super-ego in a child is not well developed, he is likely to be drawn towards delinquency [30]. According to Alexander and Staub"The criminal carries out in his action, his natural unbridled instinctual drives; he acts as the child would act if it only could. The repressed and therefore unconscious, criminality of the normal man finds a few socially harmless outlets.... The only difference between the criminal and the normal individual is that the normal man partially controls this criminal drives and finds outlets for them in socially harmless activities [31]". As regards the topic of female criminality the central tenet of Freud's theory is, female criminality according to him is due to sexual neurosis. According to him a female while she is still a child recognizes that she has inferior sexual organs and as a result becomes envious and revengeful. Another argument of Freud is that women generally do not develop a strong conscience. Deviant women according to Freud are those who imitate men and try to achieve acclaim within the masculine spheres of activity or those who reject their so called natural 'passivity'. Freud's theory uses psychology and mental disease to explain female criminality [32]. It is true that in the modern world bizarre crimes are being committed by females and the related index is still on the rise exhibiting psychological aberrations which further have contributed to the volume of nontraditional crimes committed by the fairer sex.

\section{Social Disorganisation Theory}

Society itself is dynamic in nature. Rapid urbanization and industrialization create changes in it due to which there is resultant breakdown of traditional patterns of living and values. Believers of this theory blame social disorganization for the deviant behavior. The researches by Ruth and Jordan Cavan show that the Eskimos were free from the problem of delinquency but due to their movements to the towns, loitering drunkenness and perverse sexual attitudes have crept

In them also [33]. Maladjustment due to friction created by one culture moving ahead of others is inevitable. The values which are being discussed may be values imposed by the government on the traditional values and sometimes values may be imported too. Ruth and Jordan Cavan have collected date regarding incidence of delinquency in many countries while studying the effect of social complexity problem on the crime situation in those countries [34].

In a developing country like India young females from the rural areas are found to be gullible and they suffer from the consequences of culture lag once they find themselves in the midst of the hub hub of the city life. Confused they lead themselves into criminal activities to keep up the pace of their life with the others by stealing, shoplifting, prostitution or joining illegal trades as accomplices of men. To survive in the new surrounding is their main aim and to be labeled as a misfit for them is equal to dying with shame therefore to avoid this catastrophe they may resort to legitimate or even illegitimate means. Social disorganization is only one of the causes of criminality be it male or female but its presence itself attracts potential victims who misinterpret the disorganization as a symbol of modernization, industrialization and development.

\section{Differential Association Theory of crime}

Sutherland presented a theory of differential association in his book 'Introduction to Criminology [35]'. His theory was an elaboration of the notion that cultural conflict is the main culprit behind the phenomenon of crime.

Sutherland summarized his theory of criminality as follows: "A person becomes delinquent because of an excess of definitions favorable to violation of law over definitions unfavorable to violation law.

Criminal behavior is explained as a product of learning in interaction with other persons principally 
with intimate personal groups. It is assumed that any person inevitably assimilates the surrounding culture unless other patterns are in conflict [36]', This theory propounds that criminal behavior is learnt by interaction with others in the process of communication. It is predominantly learnt in intimate personal groups. Learning of criminal behavior comprises of techniques of crime commission along with specific direction of motives, drives, rationalization and attitudes.

It is evident that the theory of Sutherland and Cressey is of general application and applies to women as much as to men. When the question is posed before Sutherland as to why the male crime rate is much higher he answers by arguing that females of all classes and ages are socialized into the same sex role. They have learnt to be nice and non-egoistic because they have been taught and conditioned to be such.

He further stresses that women are more law abiding because they are excluded from the dominant male culture. The difference in training and education of boys and girls right from their childhood leads to a differential behavior. Sutherland removes from women the education necessary to criminality or to competitive law abiding behavior. He only allows them learning which fits their perceived roles as mothers and carers; any criminality has to arise out of this [37].

More recently Giord and Rockwell have contended that learning theory and differential associations may explain female criminal activity to a large extent. They suggest that all female criminals had firm associations with positive depictions of deviant life styles. From a young age many of the women were immersed in these definitions from mothers, fathers, aunts, cousins and siblings who might be caught up in these activities [38].

\section{Home and Community Influence Theory}

The home is the cradle of human personality. Each person from the moment of birth is deeply influenced by the people around him. The baby is born not knowing what to think or how to feel about life but ready to learn and learn he does Willy nilly. From a warm, stable loving family the child learns that people are friendly, worth knowing and can be depended upon. When a family is cold, despairing, rejecting or neglectful the child learns distrusts, hostility or down right hatred of people. Such families are found in all economic, cultural, racial, national and educational backgrounds [39]. A report from Birmingham Alabama states, "If high population density, low economic value of houses, physical deterioration and lack of necessary equipment and high rate of tenancy can be evaluated as indicators of poor housing, the findings of this investigation presents objective confirmation of the general principle that poor metropolitan housing tends to be associated with high rates of delinquency and vice versa [40]. It has been seen that parents living in strained relation or behaving indecently influence the tender minds of their children negatively. When such problems cannot be handled by the child it may become delinquent. As regards the effect of home and community influence on girls, figures compiled annually by the municipal court of Philadelphia regarding home conditions of delinquent children showed that these children came from broken homes in approximately $47 \%$ of all cases. The report further showed that the factor of abnormal home life was manifest in a greater percentage of cases among delinquent girls as compared to boys[41].

Secondary community influences are another factor that male or female may be subject to, instigating $\mathrm{him} /$ her to become delinquent. Some of these secondary community influences are the newspaper, radio, motion picture, television, comics etc. For example young girls find from many movies that love can be thrilling and even pleasingly dangerous, that clothes make the woman, that men seek girls who have easy virtue, who use finesse in makeup and in wearing their clothes well, that if a girl is astute she can have the clothes and the good times she craves[42]. Girls are getting more opportunities now due to their newly acquired liberation and the media is providing the hype or we may say fuel to the fire. So many girls have run away from their homes to become famous in big cities and have landed themselves into the underworld of criminality and no doubt the secondary community influences are to be blamed to quite an extent for their misadventures. Instead of becoming a Marlin Munroe they have become a call girl, instead of landing in the tinsel town they have landed into brothels. Only later such girls realize that there is a devastating difference between reel life and real life.

Records of criminal women show clearly the positive correlation between broken homes and delinquency. Many of such females had been sexually abused at homes, had been battered by parents, guardians or siblings. The criminal is bred in the homes and send out in the society to devastate. The bitterness which they carry with themselves they distribute in the society. Lisa C. Burt of the Rochester Institute of Technology holds that whether one is male or female growing up in an environment in which one is beaten or neglected is going to cause serious traumatic repercussions and a right thinking person would be sensible enough not to concur with her statement. Giordano and Rockwell projected before the world by their research involving interviews with convicted female offenders how exposure to antisocial activities or definitions affects delinquent behavior among females [43]. Criminal behavior can be learnt through practice or by watching the environment in which one lives, by following the activities of friends, family, neighbors and teacher as well as in socially constructed environment such as books, magazines, television and films. 


\section{Anomie Theory}

The term 'anomie' was used by Durkheim a French sociologist in his work 'The Division of Labour in Society', in which it was held to be responsible for deviant behavior in the society. According to Durkheim 'anomie' constitutes the phenomenon of the relation of the individual becoming disorderly due to his act of disregard of the social norms. The non-compatibility of expectation and experience give rise to anomie[44] Merton also based his crime theory on anomie but the anomie according to him is when an individual cannot adapt himself to the values and norms of the society. It is a virtual boomerang when the norms made by the society for a conformist behavior of its members tend to produce the opposite in the form of criminal behavior. To quote Ahmed Siddique, "Robert Merton's theory of anomie, delinquency (and other forms of deviance) is a response to the unavailability of conventional or socially approved routes to success and is characteristic of lower class persons since the social structure strains the cultural values, making action in accord with them readily possible for those occupying certain status within the society and difficult or impossible for others [45].

Anomie is really the outcome of all the resultant factors of crime. In a way it is not a crime theory but the result of some or all the theories of crime. It is a phenomenon created by one or two factors or many converging factors are they social, physiological, economical, geographical, ecological etc. The comparatively low crime rate of females as compared to men can be explained by the theory of anomie. A female child is right from her childhood taught by her family and peers to be conformist, to follow the norms of the society made especially for females for example to be obedient and be an angel at home. Women's greater marriage rates and their commitment to a household shared by her husband and children reduce their readiness and aptitude to violate the law. But there is another face of the coin too encompassing.

The discussion on relationship of the phenomenon of women's liberation and anomie. At present women have almost the same opportunities in all the fields where men are already rooted and they are subject to the same strains as of their male counterparts. Deviance is bound to occur when non compatibility of expectation and experience occurs and women are no longer immune to it. Criminality of women also increases because in this era of liberation they feel strongly that equality of opportunity exists and whenever they encounter sharp restraints on it they are bound to retaliate pushed further still by the resultant feeling of unfairness. Anomie is indeed a strain theory. Frustration within the system or possibly economic necessity drives the strain ridden person to resort to criminality and females are equally prone to it just as males.

\section{Economic Theory of Crime}

Karl Marx described the violation of law generally as 'the offspring of the economical agencies beyond the control of the legislature [46]'. Ellore Fornasari of Italy found in his study that 85 to $90 \%$ of convicts belonged to poor families which constitute 60 percent of the total population [47]. Bonger stressed on the fact of crime being the motivation of the poor condition of life, the capitalistic structure of the society only worsening this situation [48]. The study made by Breckinridge and Abbot gave clear conclusions that nine tenth of the delinquent girls and three fourth of delinquent boys were from poor classes [49].

Certain quarters say- "It is envy and ambition rather than hunger or cold that stimulates much petty crime, in the same way that greed urges the big time criminals. It is not lack of clothing but perhaps the lack of expensive clothing that tempts hundreds of girls for example to become prostitutes[50]" The biggest cause of prostitution in today's modern.

Advanced world is poverty, otherwise who would enjoy sexual exploitation at the hands of strangers. But there are exception too when girls from well off families fall prey to this vice out of greed and not need so that they may easily avail of all possible luxuries of life. It is shocking to know that nowadays girls are auctioning off their virginity for economic reasons. A recent study reveals that an increasing number of female students are resorting to prostitution or other jobs in sex industry to pay rising university tuition fee [51]. It seems that dire financial crisis has overcome the moral sense of such girls and the belief again gains strength that necessity knows no law; poverty is a strong factor which forces a person to shed all inhibitions and work towards realizing unfulfilled goals either by legitimate or illegitimate means. Box and Hale pointed out that at present women are increasingly become economically marginalized. More and more women are becoming either sole or joint breadwinners of their families and due to this they are subject to the strains of economic requirement. These increased strains do explain some of the increased female criminality especially in the traditionally male criminal areas [52]. There are certain offences which have risen meteorically and are associated with female poverty; evasion of payment for television licenses is probably the most plausible example [53].

Freda Adler believed that the rise in female crime is due to the women's liberation. According to her women are seeking greater criminal opportunities due to their pursuing greater legitimate economic goals just like their male counter parts. On her assertion there were arguments everywhere that any rise in female crime was due to the increasing poverty and women were the victims of economic inequality [54].

The rising number of female involvement in 
property crimes, and the studies of women in jail for offences of fraud and embezzlement reveal that women are frequently motivated by emotional responsibility to the family and by economic necessity [55]. The latest position is that women are occupying the criminal areas which were male bastions only and economic reasons are one of the main factors behind this.

\section{Conflict Theory}

Ralf Dahrendorf's 'Conflict Theory' was a product of research on social sciences but his valuable thought reoriented criminology in a broader perspective ending its isolation from social sciences. He asserted that there are two sets of position- one domination and the other subjection and an individual in the society may belong to either of the two positions or we may say classes. He concurred with Karl Marx in considering class conflict as a factor of social change but deferred from him when latter proposed that all social changes were the result of this conflict [56]. Contemporarily Vold had also written a fine book on theoretical criminology but his theory of crime was based on group conflicts [57]. Dahrendorf and Vold led quite a few sociologists to come out with their own conflict theories for example Sellins by his Culture Conflict Theory tried to explain the causation of crime on the basis of culture conflicts within a heterogeneous complex society[58]. Vold's Group Conflict Theory simply propounded that the criminal behavior was the outcome of the behavior of minority power groups lacking sufficient power to promote and defend their interests and purposes in the legislative process. Richard Quinney was also a conflict theorist who believed that crime was the result of conflicts of groups in the context of the various institutions- political, economic, religious, kinship, educational and public. He supported the notion that law support some interests at the expense of other rejecting the pluralist

Notion that law represents the compromising of diverse interests [59]. Austin Turk was yet another propounded of yet another conflict theory who believed that it is the people who are in a superior status to make and enforce the legal rules that assign the criminal status on the inferior persons. The persons are labeled criminal if they are caught and those who commit crimes and yet not apprehended are not designated as criminals. Factors such as age, sex, race and ethnicity were included in his research, for example according to him in USA young members of racial minorities were prone to become criminals [60].

Conflict Criminology is a reaction to the traditional criminology or we may say it is the Radical Criminology. It is true that as complexity increases in the society, friction of interests of individuals is inevitable and this friction automatically increases the conflict in the society. This statement matches with Chambliss and Siedman's theory which says that as society becomes more complex, the interests of individuals within it begins to differ and this happens due to their condition of life being affected by their values which become various as complexity of society increases[61].

As regards relationship between women and conflict theories society's basic threads have been shredded by women now occupying social positions at par with men in all domains. Friction is inevitable and women make a class of their own due to the gender difference. They form a new interest group to promote their own welfare or we may say promote what they perceive as their welfare. They may either conform to or completely revolt against the existing patriarchal order of the society. Whichever way they choose friction is bound to occur and conflicts are bound to occur. Mainstream Criminology accepted the posited law and then came out with either biological, psychological ecological or social explanation for male or female offending but the radical criminologists argued that it was due to the artificial presentation of law and the

Biased way it was administered that criminality in the society is viewed. For example females are considered criminals if they are practicing prostitution but the male partners go free though they are equally to be blamed for the survival and progress of this vice. The criminal justice system would never really recognize male prostitution to be a crime and the presence of gigolos is not a fiction in this dangerously modern society but to authenticate their presence would undermine the reputation of the men behind the justice catering institutions. New crimes by women replacing the traditional ones are also due to the factor of conflict with the men to reaffirm their new founded position in society and its various institution - political, economic, religious, educational etc. Conflict is the outcome of gender stratification in the society. Rae Lesser Blumberg says. "The degree of gender stratification is inversely related to the level of economic power women can mobilize and conversely the less economic power women can mobilize the more likely they are to be oppressed physically, politically and ideologically [62]. Blumberg further feels that during this time of change when economic power of women is increasing men may feel threatened and retaliate by repressing physically and politically women's effort to gain equal power. Yet as women's relative economic power increases this increase will translate into political influence. This would result in recession in political working against women [63].

Feminists explain the position of women in society with the help of conflict theory. They argue that conflict over limited natural resources is what led men to relegate women to domesticity. Man's innate dominant nature would never agree to give power to women and the present changed temperament of women is bothering them a lot. With the gain of power 
women are indeed imitating men in all the spheres and the criminal one is no exception.

\section{Ethnic Theory}

Conflicts are bound to happen when different races with their individual

Cultures compete in the society, the competition being for the resources available and to subjugate the other to a comparatively lower position in the society. According to Katherine S. Williams there is a broad agreement that there is a large and relatively stable correlation between race and crime in the UK. Afro Caribbeans consistently have the highest conviction rates for crime; whites are the next most likely criminal group followed at some distance by Asians[64]. Many theorists believe that sociological reasons are to be blamed for this along with prejudiced crime enforcement. Smith concluded that the actual offending rate is substantially higher among black people compared to the other groups [65]. Similarly Diana Elizabeth Kendell talks about recent studies being focused on the simultaneous effects of race, class and gender behavior. She draws our attention to the study of the sociologist Regina Arnold which revealed the relationship between women's early victimization in their family and their subsequent involvement in the criminal justice system[66]. Arnold interviewed African American women behind bars who were serving criminal sentences and found that adolescent females are labeled as deviants and subsequently as criminals for refusing to participate in their own victimization [67]. It is not that females of an ethnic group commit more offences as compared to their counterpart majority group. For example some investigators have reported that criminality of black women appears to be more directly tied to structural forces [68].

One female prisoner who was African American wailed that prisonisation alone brands them of being terrible lot[69]. Female criminal are not of a particular race but the discovery that most of them are indeed of a particular one it is alarming because it shows that the most

Vulnerable section of the society may be a victim of racism. They are disadvantaged right from their childhood in a dominating society, this reaction creates deviance in them and what follows is their subjection to negligence, isolation, marginalization and powerful control practices. Even once out of prison they are still morally, socially, politically and economically disadvantaged. Such structural inequalities need to be addressed by all the societies of this civilized world and we should research more on the point why some females of a particular race are seemingly more criminal? Are they victims of social injustice or criminals by race? According to Lombroso the most advanced form of human are white males [70]. This theory of Lombroso is misplaced, hurried and loaded with inadequately researched dangerous proposition. A racist criticism of his theory is inevitable because Lombroso's atavistic traits are necessarily prevalent more in some races specially the non-whites (traits like large cranium, square jaw, dark hair etc).

\section{Low Grade Intelligence Theory}

Low grade intelligence is correlated with crime. So according to many by eliminating the criminal we get rid of stupid people. There are only a few who commit crimes because of feeblemindedness which prevent them from differentiating right from wrong [71]. Such persons cannot anticipate the consequences of their acts which may be the direct result of their incapability to cope with the realities and difficulties of life. According to a study made by Sutherland $50 \%$ of the criminals were feeble minded though this was dropped to $20 \%$ and later on during further studies some more variance was seen by the utilization of some different methods [72]. Henry $\mathrm{H}$ Goddard found mental deficiency in almost half of all criminals while Goring was convinced that the same was the main cause in almost all types of criminal behavior [73]. According to Mary

Woodland mental deficiency plays indirect role in crime causation when persons with low intelligence exhibit social maladjustment [74].

Goddard studied the inmates of sixteen reformatories and came to the result that criminals were feeble minded. He further suggested that all such individuals were potential criminals and should be either institutionalized or sterilized to disrupt this line of inheritance (He said that feeble mindedness was inherited)[75]. Hirschi and Hindling are two of the modern proponents of a link between intelligence and criminality. They found that low IQ was a good predictor of delinquency. To justify this they argued that low IQ blacks were more likely to be delinquents than high IQ blacks [76]. Similarly low IQ whites were more likely to be delinquent than high IQ whites. They found that delinquents on average had an IQ right points lower than non-delinquents but on the question whether IQ had any direct effect on criminality they steered clear and held that reduced ability of low IQ juveniles to compete in certain fields made them astray in search of recognition. Various studies globally suggest a link between criminality and low intelligence but how direct it is difficult to assume.

Deborah Denno from her studies in Philadelphia found that female chronic offenders were almost four times less likely to be in the top third of verbal IQ test scores than female non offenders. As regards female offenders same consideration held good as in male when the point of discussion was low intelligence and criminality [77]. Lombroso claimed that women had a smaller cerebral cortex which rendered them both less intelligent and further less capable of abstract reasoning but this according to him were the indices of a normal female compared to a 
normal male[78]. He could have related low intelligence with more criminality in select women but he did not do so. According to him

Females whose intelligence and physical stigmata more resembled males were criminals and were considered an anomaly among their class and the society too[79].

There had been two well-known interesting studies in this context in the USA - The Jukes [80] and The Killikaks[81]. In the study of Killikaks the damage from even one dalliance between a young man and feeble minded girl was depicted which created generations and generations worth of crime and poverty whereas in the study of the Jukes also the story was not dissimilar. Ada Juke was known as the 'mother of criminals'. The relation between crime and feeblemindedness in these two studies was a bizarre depiction. The feeble minded females in the above studies were themselves not criminals but gave birth to deviant persons who in turn carried forward the lineage giving to the world more and more deviant offsprings. It was not considered that feeble minded males or females can be manipulated and used by sharp minded criminals to achieve their criminal goals and that the criminal propensities of feebleminded persons should not be overestimated and to label them as criminals generally was a matter of apprehension.

\section{Interactionist Theory}

Interactionism or Labeling is not a single theory but instead a number of different ideas drawn together under one method. This theory is sometimes called the 'Social Reaction Theory' because it encompasses the society's attitude and reaction to the deviant rather than the study of the latter. Labeling theory has a fairly long history. As early as in 1936 Frederick Thrasher in his work on juvenile gangs observed that the official label of deviant had negative effect upon youths [82]. According to Katherine S. William, Frank Tannenbaum in 1938 said that calling someone criminal might result in him living up to the description[83]. Katherine says- "Interactionist theory analyses the way social actors.

Usually individuals have conception of themselves and of the others around them with whom they interact [84]." This theory deals with few questions like what behavior should attract the label of crime and why? How do official agencies and society use and apply these labels and what is the effect of labeling on the individual? To quote Katherine once again"Nothing is criminal until someone reacts to it in such a way as to define it as such and treat its transgressor as criminal [85]" Edwin M. Lemert described two types of deviations - primary and secondary. When deviations are rationalized and are situational and symptomatic they are primary deviations whereas when deviancy is used to defend attack or adjust the covert or overt problem due to the society's reaction to the behavior the deviations are secondary[86]. In case of primary deviations the penalties are stronger even though such deviation may be unconscious or impulsive. Such deviants are labeled as criminals and are stigmatized. Stigma only brings further deviations which are secondary in nature. The individual who is declared a 'criminal' in the eyes of the society and the law enforcement authorities becomes a criminal in his own eyes too. Either to defend or to attack those who label him so, he begins to adopt a severe delinquent role which is secondary deviation [87]. Downes and Rock argue that if actions are performed by powerful people, such action are criticized but not labeled as criminal [88]. For example there are many white collar and corporate crimes which are not within the definition of being crimes. Not only the powerful but various pressure groups argue for all manners of legal change. To quote Katherine S Williams again as regards the so called female crime of abortion- "It is not only the powerful that fight for certain legal positions. All sorts of pressure groups argue for all manners of legal changes. For example although in 1967 abortion was

Legalized in certain situations, there have always been pressure groups who argue for changing this. On one hand many groups may fight for the woman's right to choose and avail for abortion on demand and up until 28 weeks. Other groups will be arguing for the rights of the fetus or as they would call it, the child and either push for no abortion at all, or for much tighter regulation of the laws. Each is arguing to protect rights: one the rights of the mother and the other the rights of the fetus (or child). Any changing of the law results in same redistribution of benefits. One or more type of person loses by being prevented from doing as they want or being criminalized for their behavior and others gain by having their rights protected. The group that wins is the one which is successful in obtaining the support of those in a position to decide [89]."

As regards prostitution working from the interactionist approach of Edwin Lemert it is argued that transition from non-deviance to deviance is only an exaggeration of the situation experienced as a nondeviant woman and further according to Lemert all women are primary deviants as regards their contemporary female sex role[90].

In the vice of prostitution once a female is stigmatized as a deviant she finds it difficult to recover her self-image and inevitably falls further into deviant acts of prostitution. One time sex liaison gets converted into the never ending trauma of prostitution. Her new identity is superimposed on her real self and the latter dies a slow death under the onslaught of vicious and critical eyes of the society. Once a prostitute she becomes destined to be a prostitute forever, ready to offer in bondage her mind body and soul for eternity.

In a crime like prostitution only the female is 
labeled as a criminal, her male counterpart has no stigma attached for the same condemned act. A female primary deviant in prostitution converts into the secondary deviant and the male engrossed in the same act is not

Considered a deviant, neither primary nor secondary. Female under trials and first offenders learn more tricks of the trade once associated in prisons with hardcore female criminals. Here the labeling process is subtle enough so that even the primary deviants do not realize that they are being led into a sinister snare and what follows is no doubt secondary deviance automatically. The best thing about labeling.

Theory is it's recognizing the danger of pigeon holing people rather than recognizing and respecting their individuality[91]. Karlene Faith observed that since labels are culturally invested with ideological significance and applied with prejudice, it is best to avoid them. Certain women are criminalized through social processes and then labeled female offenders, delinquent woman in conflict with the law, criminals or most courteously law breakers. She further opines that recognizing the contextual bases of illegal actions and the discriminatory nature of criminalization processes as applied to either men or women, and by demystifying's labeled women by showing their diversities as well as commonalties they share as women in a gendered power structure we lose the need for label or for gendered stereotypes [92].

\section{Multiple Causation Theory of Crime}

The predominant cause of crime cannot be attributed to a single factor and human sanity would not consider this fact otherwise. No two persons may commit a single type of criminal act due to the same reason. Crime is the genus and the various criminals acts are the species and the cause behind these criminal acts are various still.

The distinguished criminologist Enrico Ferri wrote - "Crime is the result of manifold causes which although found always linked into an intricate network can be detected however by means of careful study. The factors of crime can be divided into individual or anthropological, physical or natural and social. The anthropological factors comprise age, sex, civil status, profession, domicile, social rank,

Instruction, education and the organic and psychic constitution. The physical factors are: race, climate, the fertility and the disposition of the soil, the relative length of day and night, the seasons, meteoric conditions, and temperature. The social factors comprise the density of population, emigrations, public opinion, customs and religion, public order, economic and industrial economic and industrial conditions, agriculture and industrial production, public administration of public safety, public instruction and education, public beneficence and in general civil and penal legislation. To these factors we could add many others without ever exhausting them since they include all that the universe contains not omitting a word or a gesture. What we must add however is the fact that as a whole they determine the law of criminal saturation"Just as in a given volume of water, at a given temperature, we find the solution of a fixed quantity of any chemical substance, not an atom more or less, so in a given social environment in certain defined physical conditions of the individual we find the commission of a fixed number or crimes [93]', Professor George B Vold in his 'Theoretical Criminology' stated that crime must be recognized clearly as not being a unitary phenomenon but as consisting of many kinds of behavior occurring under many different situations. No single theory therefore should be expected to provide the explanation for the many varieties of behavior involved [94].

Rise in female criminality is also attributed to multiple causes. The more traditional positivist theories explaining female criminality seem to be fading out though they remain authentic still and the modern theories linked with feminism, liberation and emancipation are coming on the forefront. Female crime has mostly been explained by biological, hormonal and psychological theories and the recent 'Generative Phases Theory' puts forward the argument that the distress the biological changes in a women give make them increasingly prone to

Delinquent acts. The traditional theories were propounded by Lombroso, Thomas, Freud and Pollak explaining female crime. The recent linking of female crime with liberation explaining female crime by control and strain theories only increases the number of factors affecting females to commit more crimes: if the society stops viewing female criminality from a masculine prism and becomes gender neutral many new causes of female crime may come to our knowledge along with the strengthening of the fact that multiple factors lead to crime gender specificity being absent.

\section{CONCLUSION}

On the matter of the application of male based theories to female crime the question mainly arises that why are they called 'male theories' and the answer is simple because they had been developed with focus on males and had been tested exclusively on male samples. According to David et al; "It is not necessary to develop entirely new concepts, scale and measures in an attempt to better understand female criminality. We disagree with the view that the classic (male based) theories are unable to understand female antisocial behavior. Instead these offer a logical conceptual and measurement starting point [95]". They further said - "This does not mean that classic male based theories/concepts must be necessarily transplanted wholesale. Theories of female crime may combine variables in a different way or suggest a different balance or emphasis [96]". 
Many of the theories which have been posited for explaining male criminality also fit female criminals into the picture though most of them view male criminality in a far more positive light than they do in the case of female criminality. With the females getting liberated they are exposed to all the factors found in the ecosystem to which the males were already exposed. The equality in status is decreasing the marginalization of females and given the opportunity and exposure they commit criminal acts similar to their male counterparts, the only

Difference seemingly the difference of hormones which both male and females are born with. The difference in crimes related to hormonal imbalances is something which differentiates male crime from female one. As regards rest of the factors be they psychological physical, biological, environmental, genetic etc they have the same effect on males as well as the females and the difference in crime rate between the two sexes may be attributed to the fact of socialization and hormones the latter specially having stronghold on the innate nature of men and women alike though the manifestation of their application may be different. Allison Morris has rightfully said, "Women like men, commit a variety of crimes for a variety of reasons, there is no single or special theory for their crimes [97]." In Carlen's word too "The essential criminal woman does not exist [98]".

\section{REFFERENCE}

1. Allison, M. (1987). Women Crime and Criminal Justice Oxford: Basil Blackwell.

2. Ibid.

3. Freda Adler, Sisters in Crime. (1975). The Rise of the New Female Criminal, New York: Mc Graw Hills, 13-14.

4. Harry. E. B., \& Negley K.T. (1959). New Horizons in Criminology (Englewood Cliffs, N Jersey: Prentice Hall, 119.

5. This belief may have got strength due to the fact of women's supposed weaknesses and vulnerabilities due to which evil spirits can easily overpower them.

6. Ghosh. S. (1986). Female Criminals in India- A Psychological study of inmates of Nari Bandi Niketan (New Delhi: Uppal Publishing House, 10.

7. See, B. Y. (1981). The European Witch Craze of the $14^{\text {th }}$ to $17^{\text {th }}$ Centuries: A Sociologist's Perspective (Chicago: Chicago University Press.

8. Katherine, S. W. (2001). Textbook on Criminology New York: Oxford University Press, 497.

9. Heinsich, K., \& Jakob, S. (1971). Malleus Maleficarum New York: Dover, 46-7.

10. Paranjpe, N.V. (2008). Criminology and Penology Allahabad: Central Law Publication, 35.

11. Gender roles reconstruction was in rudimentary form.

12. Cesare, L., \& William, F. (1985). The female offender London: Fisher Unwin, 45.

13. Ibid.

14. Ibid.

15. Ibid.

16. Ibid; 50 .
17. M.G. Schlapp, "Behavior and Gland Diseases," Journal of Heredity, 15: 12.

18. Katherine Williams, Textbook on Criminology, 491.

19. Ibid

20. Human beings have both the hormones.

21. Richard, D. (1877). The Jukes in Crime, Pauperism and Heredity (New York: Putnam, 1877), 51.

22. See, Glueck, S., \& Glueck, E. (1950). Unravelling Juvenile Delinquency (New York: Common wealth fund, 1950).

23. Charles, B.G. (1913). The English Convict: A Statistical Study (London: H.M.Statistical Study, 1913), 365-67.

24. Quoted by Steve, J. (1993). The language of the genes (London: Harper Collins, 1993), 171.

25. See, C.R. (1979). Shaw and Frederick, M Zorbaugh, Delinquency Area (Chicago: UMI Dissertation Services.

26. Ibid

27. See, F., Thrasher, M. (1927). The Gang: A Study of 1313 gangs in Chicago (Chicago:University of Chicago Press, 1927).

28. See, L.E. Cohen and Marcus Felson, "Social Change and Crime Rate Trends: A R, 44, 588-6

29. Paranjape, N.V. Criminology and Penology, 78.

30. Sigmund, F. (1960). A General Introduction to Psychoanalysis trans by Riviere John ( New York: Washington Square Press, 1960), 232.

31. Franz, A., \& Hugo, S. (1931). The Criminal, the Judge and Public: A Psycho-analytical Analysis ( New York: Macmillan Publishers,1931), 34.

32. Sigmund Freud, "Femininity" in New Introductory Lectures on Psychoanalysis, eds. J. Strachey and A. Richards (Harmondsworth: Penguin, 1973), 149.

33. Ahmad, S.(2005). Criminology (Lucknow: Eastern Book Company, 2005), 100.

34. See, R.C., \& Jordan, C. (1968). Delinquency and Crime: Cross Cultural Perspectives (Philadelphia: JB Lippincott Co).

35. See Edwin, H. (1960). Sutherland and Donald R. Cressey, Principles of Criminology (Philadelphia: Lippincott Co, 1960).

36. Ibid., 78 .

37. Katherine, S. Williams, Textbook on Criminology, 500

38. Ibid

39. National Conference on Prevention and Control of Juvenile Delinquency 1946 (From report on Home Responsibility, Washington DC, US Government Printing Office 1947).

40. Quoted in 'Focus,' 28(1949):59.

41. $43^{\text {rd }}$ Annual Report. (1956). Birmingham Alabama. 44

42. Barnes., \& Teeters, New Horizons in Criminology, 190.

43. Katherine, S. Williams, Textbook on Criminology, 286.

44. See, E.D. (1970). Suicide, (London: Routledge and Kegan Paul, 1970).

45. Ahmad Siddique, Criminology, 103.

46. Karl, M. (1985). 'Population, Crime and Pauperism', New York Daily Tribune Sept. 16, 6

47. Ellore, F.(1984). La Criminalitaele Vicende 
economiched Italia (Bocca: Turin,1894), 3-4.

48. See, W., Bonger, A. (1912). Criminality and Economic Conditions (London: Heinemann,1916).

49. Sophonisba, P. (1912). Breckinridge and Abbot Edith the Delinquent Child and the Home (NewYork: Russel Sage Foundation), 74.

50. Barnes and Teeters, New Horizons in Criminology, 152.

51. The Times of India, Sept 11, 2008, 4.

52. Steven, B., \& Chris, H. (1983). "Liberation and Female Criminality in England and Wales"., British Journal of Criminology.23;1983: 35.

53. Pantazis, C., \& Gordon, D. (1997). "Television License Evasion and the Criminalization of Female Poverty", Harvard Journal of Criminal Justice. 36: 170.

54. Freda Adler, Sisters in Crime, 13-14.

55. Ahmed Siddique, Criminology, 100.

56. See, R.D. (1959). Class and Class Conflict in Industrial Society (London: Routledge and Kegan Paul, 1959).

57. See, G., Vold, B. (1958). Theoretical Criminology (New York: Oxford University Press, 1958).

58. See Thorsten Sellin, Culture, Conflict and Crime (New York: Social Research Council, 1938).

59. Richard, Q.(1970). The Social Reality of Crime ( Boston: Little Brown,1970), 16

60. See, Austin, T. Turk. (1969). Criminality and Legal Order (Chicago: Rand Mc Nally, 1969).

61. Katherine, S. Williams, Textbook on Criminology, 446.

62. Rae Lesser Blumberg "A general theory of gender stratification;" http:/www.bolender.com/ Sociology/ Articles.

63. Ibid.

64. Katherine, S. Williams, Textbook on Criminology, 155.

65. Smith, D.J. (1997). "Ethnic Origins, Crime and Criminal Justice in England and Wales," in Ethnicity, Crime, and Immigration: Comparative and CrossNational Perspective, ed Michael Tonry (London: University of Chicago Press, 1997), 101.

66. Diana, K. (1996). Sociology in OurTimes (USA: Wadsworth Pub Co, 1996), 220.

67. Regina, A. A. (1996). "Women of Color: Processes of Victimization and Criminalization of Black Women," Social Justice, 17:153-166.

68. Hill, G., \& Crawford, E. (1990). "Women, Race and Crime," Criminology, 28 (1990):62.

69. Ibid.

70. Katherine, S. Williams, Textbook on Criminology, 489.

71. Edgar, A. Doll. (1934). "Social Adjustment of the Mentally Subnormal", The Journal of Educational Research, 28 (Sept 1934):36.

72. Sutherland, E.H. (1931), "Mental Deficiency and Crime," in Social Attitudes, ed Young Kindell (New
York: Henry Holt,1931), 357-75.

73. Ahmed Siddique, Criminology, 83.

74. Mary, W. (1955). "The Role of Low Intelligence in Delinquency," British Journal of Delinquency, 5(1955): 281-303.

75. Goddard, H.H. (1914). Feeble-Mindedness-Its Causes and Consequences (New York: Mac Millan, 1914).

76. Hirschi T., \& Hindling, M. (1977). "Intelligence and Delinquency: A Revisionist Review", American Sociological Review, 42: 571.

77. Deborah, W. (1990). Denno, Biology and Violence: From Birth to Adulthood (Cambridge: Cambridge University Press, 1990), 51-58.

78. Katherine, S. Williams, Textbook on Criminology, 490.

79. Ibid

80. See, R. D. The Jukes in Crime, Pauperism and Heredity (New York: Putnam).

81. See, H.H. (1912). Goddard the Killikak Family, A Study in the Heredity of Feeble- Mindedness, (New York: Macmillan).

82. Frederic, M. Thrasher, the Gang: A Study of 1313 Gangs in Chicago.

83. Katherine, S. Williams, Textbook on Criminology, 411.

84. Ibid

85. Ibid

86. Edwin, M. L. (1967). Human Deviance, Social Problems and Social Control (Englewood Cliffs New Jersey: Prentice Hall, 17.

87. Alvin, Gouldner, W. (1968). "The Sociologist as Partisan: Sociology and the Welfare State", American Sociologist, 3, (1968):103-16.

88. David, D., \& Paul, R. (1971). "Social Reaction to Deviance and its Effects on Crime and Criminal Careers", British Journal of Sociology, 22, 35

89. Katherine, S. Williams, Textbook on Criminology, 412.

90. Edwin, M. (1951). Lemert Social Pathology (New York: Mc Graw-Hill, 1951), 65.

91. Katherine, S. Williams, Textbook on Criminology, 424.

92. Karlene, F. (1993). Unruly Women: The Politics of Confinement and Resistance Vancouver: Press Gang Publishers, 59.

93. Enrico, F. (1911). "Studies on Criminality in France", in Modern Theories of Criminality, ed. Bernaldo de Quiros Boston: Little Brown, 20-21.

94. George, B. V. (1958). Theoretical Criminology (New York: Oxford University Press, 313-14.

95. David, M., Stoff, J.B., Jack, D. (1997). Maser, Handbook on antisocial behavior (London: John Wiley and Sons Inc): 502.

96. Ibid.

97. Allison, M. Women, Crime and Criminal Justice, 78

98. Carlen, P. (1985). Criminal Women Cambridge: Polity Press, 1985): 10. 